\title{
Public Infrastructure and Private Investment in the Middle East and North Africa
}

\author{
Pierre-Richard Agénor, ${ }^{*}$ Mustapha K. Nabli, ${ }^{* *}$ and Tarik M. Yousef ${ }^{\star \star *}$
}

\begin{abstract}
This paper examines the impact of public infrastructure on private capital formation in three countries of the Middle East and North Africa: Egypt, Jordan, and Tunisia. The first part highlights various channels through which public infrastructure may affect private investment. The second part describes our empirical framework, which is based on a VAR model that accounts for flows and (quality-adjusted) stocks of public infrastructure, private investment, as well as changes in output, private sector credit, and the real exchange rate. We propose two aggregate measures of the quality of public infrastructure and use principal components to derive a composite indicator. The impulse response analysis suggests that public infrastructure has both "flow" and "stock" effects on private investment in Egypt, but only a "stock" effect in Jordan and Tunisia. But these effects are small and short-lived, reflecting the unfavorable environment for private investment in our sample of countries. Reducing unproductive public capital expenditure and improving quality must be accompanied by reforms aimed at limiting the investment to infrastructure capital that crowds in the private sector. At the same time, other improvements to the environment in which domestic investment operates are crucial to stimulate growth and job creation in the region.
\end{abstract}

World Bank Policy Research Working Paper 3661, July 2005

The Policy Research Working Paper Series disseminates the findings of work in progress to encourage the exchange of ideas about development issues. An objective of the series is to get the findings out quickly, even if the presentations are less than fully polished. The papers carry the names of the authors and should be cited accordingly. The findings, interpretations, and conclusions expressed in this paper are entirely those of the authors. They do not necessarily represent the view of the World Bank, its Executive Directors, or the countries they represent. Policy Research Working Papers are available online at http://econ.worldbank.org.

*School of Economic Studies, University of Manchester, United Kingdom, and Centre for Growth and Business Cycle Research (pierre-richard.agenor@manchester.ac.uk); ${ }^{* *}$ World Bank (mnabli@worldbank.org); and ${ }^{* *}$ School of Foreign Service, Georgetown University (youseft@ georgetown.edu). We are grateful to Nihal Bayraktar for technical support and participants at a seminar at the World Bank for helpful comments on an earlier draft. 


\section{Table of Contents}

I. Introduction

II. Public Infrastructure and Private Investment: Transmission Channels

1. Complementarity and Crowding-out Effects

2. Indirect Output and Relative Price Effects

III. VAR Specification

IV. The Data

1. Overall Trends

2. Flows and Stocks of Public Infrastructure

3. Quality Indicators

V. Estimation and Variance Decompositions

VI. Impulse Response Analysis

1. Shock to Public Spending on Infrastructure

2. Shock to Public Capital in Infrastructure

VII. Policy Implications

References

Appendix A--Public Investment and Private Capital Formation: Recent Evidence Appendix B--Data Sources and Definitions

Figures 


\section{INTRODUCTION}

According to conventional wisdom, the poor growth and employment performance of the Middle East and North Africa (MENA) region is primarily due to the "slow, uneven and hesitant pace" of structural reforms launched in the late 1980s and early 1990s (see World Bank (2003a) and Richards and Waterbury (1996)). ${ }^{1}$ In particular, governments in the region continue to dominate most economies, with pervasive involvement in production, labor markets, banking systems, and social services. Despite efforts to reduce their size, the share of MENA's public sectors in output and employment still exceeds the average for developing and industrialized countries. In addition to the size and scope of government intervention, private sector development in the region continues to be stifled by limited progress in building market-oriented institutions and in integrating the region into the world economy (see World Bank (2003b)). As a result, the economic recovery of the 1990s was weak, labor productivity remained low, and unemployment rates continued to increase.

The absence of dynamic private sectors in MENA's economies has been especially felt in the area of investment. Observers in the early 1990s had taken the view that the public sector has "over invested" and that public investment competes, rather than fosters, private investment (see Page (1998) and World Bank (1995)). But the decline in public investment rates was not always compensated by a rise in private investment. As a result, capital accumulation rates on a per worker basis stagnated in the past two decades (see Nabli and Keller (2002)). Indeed, with the exception of Sub-Saharan Africa, MENA has the lowest private investment ratios among developing regions. Moreover, in countries where public investment levels remained high, the productivity of capital was limited. The very nature of the network utilities that were built to provide infrastructure services (vertically and horizontally integrated state monopolies) often resulted in weak delivery of services such as

${ }^{1}$ See World Bank (2004) for a review of employment and growth outcomes in the 1990s and their links to trends in physical and human capital accumulation. Elbadawi (2004) emphasized the role of conflict and instability whereas Hakura (2004) found that excessive government intervention and poor institutions were key factors hampering growth. 
electricity, natural gas, telecommunications, railroads, and water supply. Common problems included low productivity, high costs, bad quality, insufficient revenue, and shortfalls in maintenance spending (see World Bank (1994) and Kessides (2004)). The low productivity of public investment is apparent in recent growth accounting exercises showing that contribution of physical capital accumulation to growth in MENA countries has declined over time, despite the fact that there has been no attempt in the existing literature to separate explicitly the growth in public and private capital. $^{2}$

The extent to which public investment especially in infrastructure complements or crowds out private investment and the role of quantity versus quality in the productivity of public investment in MENA remain largely unknown. To date, there have been few empirical studies focusing on these issues in the region (see Appendix A for a review of studies linking public investment to private capital formation and growth in developing countries). In an early paper on Egypt, for instance, Shafik (1992) found that public investment tends to crowd out private investment through its effect on credit markets, and to crowd it in through investment in infrastructure. Everhart and Sumlinski (2001), using panel regression techniques and a proxy for the quality of public investment, find no significant effect of public investment on private investment in MENA. Dhumale (2000), using a model that accounts for credit to the private sector and the accelerator effect, finds that public investment in infrastructure appeared to have a crowding out effect in oil-exporting countries, and a crowding-in effect in the non oil-exporting countries. Mansouri (2004) finds that public capital had a positive effect on private investment in Morocco.

However, existing studies are lacking in at least three respects. First, they seldom make a clear distinction between the flow effect of public investment, and the stock effect of public capital. But this is crucial, given that the transmission channels

\footnotetext{
2 The same observation applies to the growth in total factor productivity, which has been either negative or below international levels since the 1980s (Nabli and Keller (2002)). The efficiency of public spending on education has also been low, limiting the contribution of advances in educational attainment in the region to growth (see Pritchett (1999) and World Bank (2004)).
} 
are substantially different. Second, these studies do not always account for the simultaneous relationships between public investment and capital, private capital formation, and other variables like output growth, relative prices, and private sector credit. Third, the treatment of dynamics in these studies is sometimes crude if not inexistent. All three issues are addressed in this paper, which assesses quantitatively the impact of public infrastructure on private capital formation in three MENA countries: Egypt, Jordan, and Tunisia.

The remainder of the paper is organized as follows. Section II provides a brief overview of direct and indirect channels through which public infrastructure (flows and stocks) may affect private investment. Section III describes the vector autoregression (VAR) model that we use to assess the links between public infrastructure and private capital formation. Section IV examines the data and the construction of our quality measures of the public capital stock in infrastructure. Estimation results and variance decompositions are discussed in Section V. In Section VI impulse response functions are computed to assess the dynamic effects of a shock to public infrastructure expenditure and the public infrastructure capital stock. The last section draws together some policy implications of our analysis.

\section{PUBLIC INFRASTRUCTURE AND PRIVATE INVESTMENT: TRANSMISSION CHANNELS}

Public infrastructure investment and capital can affect private investment through various channels. For the purpose of this study, and given the empirical technique that we use later on, it is convenient to classify these channels into two broad sets of effects: complementarity and crowding-out effects, and output and relative price effects.

\section{Complementarity and Crowding-Out Effects}

The complementarity effect asserts that public capital (as opposed to public investment) in infrastructure may stimulate private physical capital formation because 
of its impact on private activity. By raising the marginal productivity of private inputs (both labor and capital), it raises the perceived rate of return on, and increases the demand for, physical capital by the private sector. ${ }^{3} \quad$ Alternatively, a complementarity effect between public capital in infrastructure and private investment may operate through adjustment costs. This idea, formalized for instance by Turnovsky (1996) in a growth context, is based on the view that the availability (and quality) of public capital in infrastructure affects some of the costs that firms may incur when investing. For instance, a better road network may reduce expenses associated with the construction of a new factory or the transportation of heavy equipment. In large countries, the impact on unit production costs and the productivity of private capital can be substantial (Cohen and Paul (2004)). By lowering production costs and raising the expected rate of return, public capital in infrastructure may have a strong impact on private capital formation.

Of course, the positive effect of public capital on the marginal productivity of private inputs may hold not only for infrastructure but also for public capital in education and health, which may enhance the productivity of labor. Other components of current public spending, related for instance to the enforcement of property rights, can also increase the productivity of the economy and exert a positive indirect effect on private investment. But infrastructure capital may have a particularly large effect in countries where initial stocks are low and basic infrastructure services (electricity and communications, for instance) are lacking.

Nevertheless, to the extent that public investment in infrastructure displaces or crowds out private investment, its net positive impact on private capital formation can be highly mitigated. Such crowding-out effects tend to occur if the public sector finances the increase in public investment through an increase in distortionary taxes-which may increase incentives for private agents to evade taxation, or reduce the

\footnotetext{
${ }^{3}$ Greater availability of public capital in infrastructure could in principle also reduce the demand for private inputs, at a given level of output (net substitution effect). But if inputs are gross complements (as is the case in general), higher availability of public capital will always increase the marginal productivity of private inputs. Moreover, public and private physical capital are likely to have a high degree of complementarity, that is, a small elasticity of (net) substitution.
} 
expected net rate of return to private capital, and therefore the propensity to invest. A similar effect on private capital formation may occur if the increase in public infrastructure investment is paid for by borrowing on domestic financial markets, as a result of either higher domestic interest rates (in countries where market forces are relatively free to operate) or a greater incidence of rationing of credit to the private sector. ${ }^{4}$ Moreover, if an investment-induced expansion in public borrowing raises concerns about the sustainability of public debt over time (that is, the perceived risk of default), and strengthens expectations of a future increase in taxation, the risk premium embedded in interest rates may increase. ${ }^{5}$ By raising the cost of capital and negatively affecting expected after-tax rates of return on private capital, this increase may have a compounding effect on private investment. Private investors may revise downward their investment plans because of anticipated hikes in tax rates to cover the increase in government investment.

\section{Indirect Output and Relative Price Effects}

Public investment and capital in infrastructure may also affect private capital formation indirectly, through changes in output and relative prices. As noted earlier, public capital in infrastructure may increase the marginal productivity of existing factor inputs (both capital and labor), thereby lowering marginal production costs and increasing the level of private production. In turn, this scale effect on output may lead, through the standard accelerator effect, to higher private investment (see Chirinko (1993)). Moreover, if there are externalities associated with the use of some production factors (for instance, learning-by-doing effects resulting from a high degree of complementarity between physical capital and skilled labor), a positive growth effect may also result. An improvement in the stock of public capital in

\footnotetext{
${ }^{4}$ Note that any component of government expenditure (not only infrastructure investment), as long as it is financed through domestic borrowing, may lower private investment by driving interest rates up or increasing the incidence of credit rationing.

${ }^{5}$ In a small open economy with open capital markets facing a fixed world interest rate, crowdingout effects through a rise in domestic interest rates cannot occur. But for small developing countries, the supply curve of foreign capital is upward-sloping rather than horizontal. In such conditions, and if the risk premium faced on world capital markets is positively related to the debt-to-GDP ratio, an increase in domestic public debt induced by a rise in public investment in infrastructure may lead to both lower credit to the private sector and higher domestic interest rates.
} 
infrastructure may therefore affect the rate of total factor productivity growth, independently of its effect on private capital accumulation.

Public infrastructure can also affect private investment indirectly through its "flow" effect on the price of domestic consumption goods relative to the price of imported goods, that is, the (consumption-based) real exchange rate. An increase in public investment in infrastructure for instance will raise aggregate demand and domestic prices (in addition to stimulating output). If the nominal exchange rate does not depreciate fully to offset the increase in domestic prices, the domestic-currency price of imported consumption goods will fall in relative terms (that is, the real exchange rate will appreciate), thereby stimulating demand for these goods and dampening domestic activity. The net effect on output may be positive or negative, depending on the intra-temporal elasticity of substitution between domestic and imported goods. If this elasticity is low (as one would expect in the short run), the net effect on output may be positive, so that private investment may indeed increase. At the same time, to the extent that the increase in government spending on infrastructure raises the price of domestic capital goods, and the switch in private consumption demand toward imports translates into a nominal appreciation, the domestic-currency price of imported capital goods will fall in relative terms, resulting in a drop in the user cost of capital and an increase in private investment. This relative price effect may be particularly important in developing countries where a large fraction of capital goods used by the private sector are imported.

In addition to these effects changes in domestic prices and the real exchange rate induced by an increase in the flow of public investment in infrastructure may affect private investment through both demand- and supply-side effects on output. On the demand side, the increase in domestic prices may lower private sector real wealth and thus expenditure; if this effect is sufficiently large (relative to the increase in public spending) to entail a fall in domestic absorption, firms may revise their expectations of future demand and lower investment outlays, through a "reverse" accelerator effect. On the supply side, the real appreciation may lead to a shift in resource allocation toward the nontradable goods sector, thereby stimulating 
investment in that sector and depressing capital formation in the tradable goods sector. The net effect may be a lower growth rate of output, and thus lower investment as a result of an expected reduction in demand growth. At the same time, however, if the nominal exchange rate is flexible, and if it does not depreciate fully in response to the increase in domestic prices (as a result of an increase in the demand for imported goods, for instance), the real cost of imported intermediate inputs may fall-thereby stimulating output and private investment.

It is important to note that both the direction and the strength of the various effects described above can vary over time and depend to a very large extent on the environment in which private investors are operating. For instance, the relationship between public and private investment may be one of substitution in the short run, and one of complementarity in the long run, depending on how productive public investment is. That is, in the short term, the crowding-out effect may predominate (because the pool of resources available to finance public and private investment is limited), whereas the complementarity effect may prevail in the long term, as a result of strong supply-side effects. Thus, using dynamic models is essential to study the relationship between public infrastructure and private capital formation, beyond the need to account for gestation lags. At the same time, it is important to control for indirect effects that operate through changes in output, the real exchange rate, and possibly interest rates or credit.

Finally, it I also worth noting that there may be a feedback effect through public investment itself; indeed, to the extent that the rise in private investment stimulates output and leads to higher tax revenue, public investment may increase further, as a consequence of the additional resources at the disposal of the public sector. These dynamic and feedback effects are key reasons for choosing a VAR framework for our empirical analysis, as discussed next. 


\section{VAR SPECIFICATION}

The foregoing discussion suggests that it is important, in assessing the link between public infrastructure and private investment, to account for both the flow and stock of public infrastructure, and to control for simultaneous interactions between these variables and output, the real exchange rate, and financial variables (either interest rates or private sector credit). Accordingly, we opted to use a VAR approach to study the relationship between public investment and private capital formation in MENA. VAR models offer a number of advantages over the specification and estimation of a structural model. First, in developing countries in general, it has proved difficult to estimate robust structural models of private investment (see Agénor (2004)). VAR models offer a way of analyzing the dynamic relationship between our two main variables without having to fully specify a structural model of private capital formation. The lumpy nature of much infrastructure investment implies that the full impact of investment in, say, roads or telecommunications, may be felt only after several years; VAR models allow us to take into account delayed responses with a parsimonious lag structure. Second, VAR models explicitly recognize the endogeneity of public infrastructure investment and capital-which may result, as noted above, from the feedback effect of private investment on output (through tax revenue). Third, VAR models provide a convenient common framework for examining investment behavior in a cross-country study. Using a uniform single regression model would amount to imposing strong restrictions on specification and the direction of causality among the variables. As a result, models of this type tend to be prone to misspecification errors resulting from "missing variables" bias and the neglect of dynamic feedbacks - a particularly important problem when the purpose of the study is to conduct simulation experiments.

The use of VAR models to study the impact of public investment on private capital formation is by no means new. For instance, Mittnik and Neumann (2001) examined the impact of public investment using impulse response functions derived from a VAR consisting of public investment, private investment, public consumption, 
and output. Ghali (1998) used a VAR (or, more precisely, a vector error correction model) with real GDP, public investment, and private investment. Ligthart (2000) used an unrestricted VAR in output, public capital, private capital, and employment for Portugal. Belloc and Vertova (2004), using a vector error-correction approach, found a complementarity relationship between public and private investment, and a positive effect of investment on output in 6 out of 7 highly-indebted poor countries. Finally, Voss (2002) specified a VAR with ratios of public and private investment to GDP, the growth rates of the relative prices of public and private investment goods, the real interest rate, and the growth rate of GDP. All these studies, however, suffer from three major limitations in terms of their specification: a) they do not generally make a distinction between the flow of public investment and the stock of public capital; $b$ ) and they do no always account for potential crowding-out effects; and $c$ ) they do no account for indirect effects of public investment on private capital formation through the real exchange rate. Belloc and Vertova (2004), for instance, used a trivariate VAR, with no control for factors other than output. As emphasized earlier, the channels through which public infrastructure affects private investment involve both "flow" effects (which operate through aggregate demand, relative prices, and the financial sector) and "stock" effects (which operate both through the demand and the supply sides).

Our VAR improves on existing studies in all three respects. We include the following variables in our specification: the flow of public capital expenditure on infrastructure as a share of GDP, the stock of public capital in infrastructure as a share of GDP, private capital formation as a share of GDP, the ratio of private sector credit to GDP, real GDP growth, and the real exchange rate. The actual growth rate of output is used as a proxy for expected changes in aggregate demand and captures dynamics associated with the accelerator effect. Changes in private sector credit account for possible crowding-out effects associated with government spending through changes in credit rationing. We chose a credit variable instead of Interest rates, because these rates remained largely under government control for 
much of the estimation period. ${ }^{6}$ Changes in the real exchange rate account for both the relative price effect of an increase in domestic absorption, and indirect effects on the user cost of capital and the price of imported inputs, as discussed earlier. ${ }^{7}$

To assess whether the stock of public capital in infrastructure should be included in the VAR (in addition to the associated flow), we performed an exogeneity test based on estimating both the "unrestricted" and "restricted" VAR models (that is, with and without the public capital stock). ${ }^{8}$ Finally, to calculate variance decompositions and identify impulse response functions, we use the standard Choleski decomposition. Specifically, to implement this decomposition, the disturbances in the model are assumed to follow the following causal ordering: credit-to-GDP ratio; public infrastructure spending ratio; public infrastructure capital ratio; the rate of change of the real exchange rate; the growth rate of GDP; and the private investment ratio. The reasoning behind this ordering structure is that whereas public expenditure decisions or the public capital stock can affect private sector investment decisions in the short run (within one period), the reverse is not true. Thus, public expenditure on infrastructure does not depend contemporaneously on private investment, an assumption which we take to be consistent with treating public investment as exogenous (at least with respect to private investment) in structural models. Public expenditure on infrastructure naturally precedes the public capital stock. By contrast, the real exchange rate, private investment, and output growth, are all assumed to respond immediately (within a year) to public investment. Private sector credit is

\footnotetext{
${ }^{6}$ Mansouri (2004), in his study on Morocco, uses the real deposit rate as a proxy for the cost of borrowing. However, this is a debatable assumption, given that official nominal interest rates remained under control during much of his estimation period.

${ }^{7}$ In principle, we should use changes in the ratio of the price of imported investment goods to the domestic price of these goods (or the national accounts deflator of private investment), as for instance in Mansouri (2004). However, sufficiently long time series were not available for our sample.

${ }^{8}$ Let $\Omega_{U}$ and $\Omega_{C}$ denote the variance-covariance matrices of the residuals associated with the unrestricted and restricted models, respectively, and define the likelihood ratio statistic, $\lambda$, as

$$
\lambda=(T-C)\left(\log \left|\Omega_{C}\right|-\log \left|\Omega_{U}\right|\right),
$$

where $\left|\Omega_{C}\right|$ (respectively $\left|\Omega_{U}\right|$ ) is the determinant of $\Omega_{C}$ (respectively $\Omega_{U}$ ), $T$ the number of observations, and $c$ the number of parameters (equal to the number of lags times the number of variables, plus one for the constant term) estimated in each equation of the unrestricted system. This statistic has a $\chi^{2}$ distribution with degrees of freedom equal to the number of restrictions in the system, which is in turn equal to one times the number of lags.
} 
considered the most "exogenous" variable, with the implicit view being that it is largely under the control of (risk-averse) banks.

\section{THE DATA}

We begin by examining the data on private and public investment in the three countries in our sample. Next, we consider the evolution of public capital expenditure on infrastructure and describe how these flows are converted into stocks. We then explain how our basic indicators of the quality of public capital in infrastructure are constructed, and how they are used to derive a composite indicator.

\section{Overall Trends}

Figure 1 shows the evolution of public and private investment ratios to GDP since the mid-1960s in Egypt, the mid-1970s in Jordan, and the early 1970s in Tunisia. The share of public investment in GDP has displayed substantial volatility over time in all three countries, but has been on a downward trend in Egypt and Jordan since the late 1980s. Private investment ratios have at the same time been subject to large fluctuations, most significantly during the 1980s and 1990s-a period characterized also by large fluctuations in GDP in the region as a whole. In Egypt, following a steady increase from the mid-1960s to the late 1980s, the share of private investment in GDP has averaged 10 percent. In Jordan and Tunisia, private investment ratios have declined significantly since the peaks of the early 1990s, fluctuating in recent years between 12 and 15 percent.

\section{Flows and Stocks of Public Infrastructure}

National Accounts data on public investment in infrastructure are generally not available. For the purpose of our study, we used government budget data published in the IMF's Government Finance Statistics (GFS) Yearbook to build an estimate. Specifically, as discussed in Appendix B, we calculated capital expenditure on infrastructure by adding capital outlays on various categories, including construction, 
transportation, and communication. Of course, all capital expenditures on these categories do not necessarily represent "investment", as conventionally defined; some components of these outlays may be related to maintenance operations. However, we did not have sufficient information to refine the GFS estimates.

Figure 2 shows the evolution of total capital expenditure in proportion of GDP, and capital expenditure on infrastructure both as a share of total public expenditure (including current spending) and as a share of total capital expenditure only. The figure shows a declining trend in all three ratios since the early 1980 s for Jordan and the late 1980s for Tunisia. For all three countries, the behavior of the ratio of total capital expenditure to GDP is consistent with the evolution of total public investment displayed in Figure 1. As a proportion of total capital outlays, the share of capital expenditure on infrastructure has averaged 30 percent for Jordan and almost 40 percent for Tunisia in recent years. For Egypt, by contrast, there are large fluctuations during the past 40 years, but no clear trends. In recent years, the share of capital expenditure on infrastructure in total capital outlays has fluctuated between 45 and 50 percent.

Using our flow data on infrastructure spending, we calculated the stock of public capital in infrastructure, using the perpetual inventory method and the GDP deflator to estimate real values in constant local prices. This procedure is, of course, subject to limitations. ${ }^{9}$ Differences in the efficiency of the public sector and the price of infrastructure capital, in particular, means that the same level of capital spending on infrastructure may yield very different results across countries. We account for quality ex post by using various indicators, as discussed below. More generally, the use of perpetual inventory methods to calculate stocks from expenditure flows may introduce systematic errors in stock estimates. At the same time, however, it should be noted that adequate price variables for public infrastructure are difficult to

\footnotetext{
${ }^{9}$ See Hulten (1990) for a detailed discussion of the conceptual and measurement problems involved in constructing capital series. To calculate the public capital stock, we used a uniform depreciation rate of 2.5 percent. By comparison, Nehru and Dhaneswar (1993) used a uniform rate of 4 percent, whereas Larson et al. (2000) use alternative values of 4 and 6 percent, to estimate aggregate stocks of capital. However, sensitivity analysis showed that our empirical results are not unduly sensitive to our particular choice.
} 
construct (given that infrastructure services are often provided free of charge) and that errors in estimating initial stocks (a common problem with this methodology) tend to become less significant over time. In addition, the alternative of using actual stocks of infrastructure (such as roads, electricity production, or water supply) was not feasible due to lack of data; the only complete series that we had at our disposal was that of electricity production, but it was felt that using it as a the sole indicator of quality of the overall stock of infrastructure was not warranted.

\section{Quality Indicators}

In assessing the impact of the public capital stock in infrastructure on private investment, it is important to account not only for the absolute amount of that stock, but also for the quality (or efficiency) with which public capital is used. ${ }^{10} \mathrm{~A}$ common procedure to estimating the quality of public infrastructure capital is to calculate the index proposed by Hulten (1996). His composite measure of public capital efficiency is based on four basic indicators: mainline faults per 100 telephone calls for telecommunications; electricity generation losses as a percent of total electricity output; the percentage of paved roads in good condition; and diesel locomotive utilization as a percentage of the total rolling stock. In practice, researchers have found that these individual quality indicators tend to be highly correlated with the quantities of each type of infrastructure. ${ }^{11}$ Thus, much of the variation in infrastructure quality may be well captured by variations in its quantity.

The individual quality indicators proposed by Hulten (1996) are subject to limitations. For instance, electric power losses include both "technical" losses, reflecting the quality of the power grid, and theft; in general, the breakdown between

\footnotetext{
${ }^{10}$ According to the World Bank (1994, p. 1), technical inefficiencies in roads, railways, power, and water in developing countries caused losses equivalent to a quarter of their annual investment in infrastructure in the early 1990s. See Estache (2004) for a further discussion.

${ }^{11}$ Calderón and Servén (2004a, p. 19) found a high degree of correlation between the individual quality indicators listed above with the related quantities of infrastructure (that is, between power generation capacity and power losses, or between road density and road quality, the latter measured by the proportion of paved roads in total). In a companion study (Calderón and Servén (2994b, p. 11)) they obtain the same result with their two synthetic indicators of quantity and quality of infrastructure.
} 
the two components is not available. Moreover, these series tend to fluctuate significantly over time, and these fluctuations are not always easy to interpret as changes in quality as opposed to, say, measurement errors or "abnormal" shocks. More importantly in the present case, these indicators were not all available for our group of countries, and when they were, many data points were missing. Despite using a combination of local and international sources-including the World Development Indicators of the World Bank and Canning's (1998) database on physical infrastructure stocks-we were unable to "piece together" complete series.

We therefore followed another approach, which consisted in, first, defining two alternative quality indicators and, second, combining them to create a composite indicator. Our first individual indicator is an "ICOR-based" measure. Aggregate ICORs (calculated as the ratio of total domestic investment divided by the change in output) are commonly viewed as a measure of the efficiency of investment. Here we apply this idea to public infrastructure, by calculating an ICOR coefficient defined as public capital expenditure on infrastructure divided by the change in GDP. We then invert this measure and take a 3-year moving average, in order to smooth out the behavior of the series over time. Figure 3 shows the behavior of our ICOR-based quality indicator. The results suggest that whereas quality seems to have improved in recent years in Tunisia, it has deteriorated in Egypt and Jordan.

Our second indicator is an "excess demand" measure. Our premise is that, if growth in the demand for infrastructure services tends to exceed growth in supply, pressure on the existing public capital stock will intensify and quality will deteriorate. To construct these indicators we proceeded in two steps. First, we calculated individual indicators of "excess demand" for three categories of infrastructure services: electricity; telephone mainlines; and paved roads. To estimate demand for infrastructure service $h$, we applied the annual growth rate of real GDP per capita to the stock of public capital in $h$ at the base period. We used elasticity values of unity in

Esfahani and Ramírez (2003, p. 446) also note the existence of a close correlation between stocks of infrastructure capital and quality in their sample. 
each case.$^{12}$ To estimate supply of infrastructure service $h$, we used the actual stock of $h$. We then calculated individual indicators of excess demand for each component of infrastructure services by taking the ratio of supply to "predicted" demand. This ratio gives therefore an indicator of adequacy between supply and demand; a fall in the ratio would indicate excessive pressure on existing infrastructure and therefore a deterioration in quality. Second, we calculated a "composite" excess demand indicator for each country. To do so we used the same procedure used by Hulten (1996) to calculate his quality index, that is, we standardized each of the three series (by subtracting the mean and dividing by the standard error) and calculated the unweighted, arithmetic average of the standardized series.

Continuous annual time series for all three of the infrastructure services referred to earlier were not available for the whole estimation period. For instance, data on roads (in terms of kilometers per capita) were available only since 1990 . We therefore calculated the composite indicator with all the information available in the base period to begin with, and added additional series as they became available. Figure 4 shows the behavior of these series, which have been normalized to a value of unity in 1977, to facilitate comparisons across countries. Again, a three-year moving average is used, in order to smooth out spikes possibly associated to measurement errors. In contrast to our ICOR-based indicator, the results appear to suggest that quality improved in all three countries in recent years.

Differences in the behavior of our two quality indicators may appear problematic, given that there is no strong a priori reason for choosing among them. We thus follow the same approach as Calderón and Servén (2004b), who define several standard quality indicators (based on electricity losses, percentage of paved roads, and telephone faults, given that they use stocks of electricity, roads, and

\footnotetext{
${ }^{12}$ In their estimation of demand functions for infrastructure services based on panel data, Fay and Yepes (2003, p. 8) found long-term elasticities of 0.375 for electricity, 0.5 for telephone mainlines, and 0.14 for paved roads. These estimates differ quite significantly from our values of unity. However, the Fay-Yepes estimates refer to low- and middle-income countries in general, so there is no indication that they are adequate for MENA countries in particular-or, for that matter, the three countries in our sample. Moreover, in their regressions, there is no price (or user cost) variable, so their estimated income elasticities may be biased.
} 
telephones in their regressions) and use principal components analysis to "summarize" the information contained in all of these series. Specifically, we applied principal components analysis to the two quality series that we defined earlier. ${ }^{13}$ The results show that the first principal component explains 64 percent of the total variance of the underlying variables for Egypt, 68 percent for Jordan, and 55 percent for Tunisia. After renormalization, we use a weighted average of the two principal components, using as weights the proportion of total variance explained by each component, as our quality indicator.

\section{ESTIMATION AND VARIANCE DECOMPOSITIONS}

As noted earlier, our VAR model consists of public capital expenditure on infrastructure as a share of GDP; private investment as a share of GDP; the growth rate of real GDP; the ratio of private sector credit to GDP; the rate of change of the real exchange rate; and possibly the public capital stock in infrastructure. Prior to estimation, we examined the stationarity properties of each of these variables with Augmented Dickey-Fuller and Phillips-Perron unit root tests. The results (which are available upon request) indicated that all series are either stationary or trend stationary. As a result, we included an exogenous time trend in the VAR.

The first step in the estimation was to verify that the public capital stock in infrastructure "belongs" to the VAR. To do so we applied the exogeneity test described earlier. The results indicated that the null hypothesis (exclusion of the public capital stock from the VAR) was soundly rejected by the likelihood ratio test. We then chose the optimal lag length, using the Akaike criterion. Given the relatively small size of the sample, we were able to compare models with only one and two lags. ${ }^{14}$ The Akaike criterion suggested a lag of 2 years for Egypt, and one year for

\footnotetext{
${ }^{13}$ See, for instance, Jackson (1991) for a description of principal components analysis. The first step in this analysis is to put all of the data in standard units. By doing so, all of the transformed variables have unit variances and the resulting covariance matrix is actually the correlation matrix of the original variables.

${ }^{14}$ Specifying a maximum lag length that is too short may impose unwarranted zero restrictions. At the same time, imposing a lag length that is too long may result in inefficient parameter estimates, because the model is over-parameterized.
} 
Jordan and Tunisia. Lags of this order may not be sufficient to properly account for long gestation periods associated with some types of public investment, but the lack of degrees of freedom prevented us from experimenting with higher-order systems. Nevertheless, it should be noted that we introduce explicitly the stock of capital in infrastructure itself, and that our hypothesis is that the (quality-adjusted) stock produces a proportional flow of services. Simulations related to changes in the public capital stock are therefore unaffected by the problem of gestation lags.

The extent to which exogenous changes (or innovations) in public infrastructure and other variables in the VAR model have affected the behavior of private capital formation can be gauged by computing the proportion of the variance of the forecast error for the private investment-to-GDP ratio that can be attributed to variations in each variable at different forecast horizons. Figures 5, 6 and 7 show these variance decompositions, at a horizon of up to 24 periods. For Egypt, although shocks to the private investment ratio account for a large fraction (almost 64 percent) of its variance in the short run, in the long run it explains only 11 percent. The fraction explained by the credit-to-GDP ratio, by contrast, increases from about 4 percent in the short term to 24 percent in the long term. So does the share of public capital spending on infrastructure, whose share rises from 1 percent to almost 28 percent. By contrast, the share of public capital remains relatively stable over time, at about 89 percent. For Jordan, the credit-to-GDP ratio also plays an important role in explaining the variability of the private investment ratio; it accounts for 62 percent in the short term, and 52 percent in the long term. Public spending on infrastructure and public capital play a much less significant role than in Egypt, explaining only about 8 percent of the variance of private investment in the long term. But real exchange rate shocks have a much larger impact than in Egypt, accounting for about a quarter of the variance of private investment in the long term. For Tunisia, the credit-to-GDP ratio appears to play a negligible role; in both the short and the long term, it explains barely 3 percent of variations in the private investment ratio. Public expenditure on infrastructure and public capital, by contrast, explain about a third of these fluctuations in the long term. Shocks to private investment itself explain a large fraction of the variance of that variable, even in the long term. Overall, therefore, the 
variance decompositions suggest that public spending on infrastructure and public capital account for only a small fraction of the variance of private investment in Jordan, and not much more than a third of this variance for Egypt and Tunisia. Other shocks, as well as "own" innovations, appear to have mattered a lot more.

\section{IMPULSE RESPONSE ANALYSIS}

We now examine the impulse response functions associated with a shock to public spending on infrastructure and our quality-adjusted measure of public capital. As noted earlier, this analysis is important because it allows us to assess to what extent flows and stocks of public infrastructure affect private investment, taking into account crowding-out effects and the possibility that indirect effects may occur through changes in the growth rate of output and the real exchange rate.

\section{Shock to Public Spending on Infrastructure}

The left-hand side of Figure 8 shows the response over a 10-year horizon of the private investment rate to a one-standard deviation innovation in the ratio of public capital expenditure on infrastructure in GDP. The solid lines in the figure represent the impulse response functions themselves, whereas the dotted lines are the associated 95 percent upper and lower confidence bands. ${ }^{15}$

The results indicate that the shock to the public capital expenditure ratio has a positive and statistically significant effect on the private investment rate beginning in period 2 and lasting for 2 periods in Egypt, and no effect in Jordan and Tunisia. Moreover, in the case of Egypt and Jordan, the shock has no effect on the growth rate of output, the real exchange rate, or the credit ratio. By contrast, in the case of Tunisia, the real exchange rate appreciates and output falls significantly in the second period. Thus, the lack of significance of a public spending shock on private investment in Tunisia may result from the fact that the resulting increase in aggregate 
demand (which tends to raise domestic prices) is offset by an adverse real wealth effect on private consumption expenditure, at the same time that the real appreciation leads to a contraction in output. In turn, this contraction in activity may offset the initial positive impact of public expenditure on private investment through a "reverse" accelerator effect.

\section{Shock to Public Capital in Infrastructure}

The right-hand side of Figure 8 displays the response of the private investment ratio to a one-standard deviation innovation in the ratio of public infrastructure capital to GDP. The results show that the shock has a positive and statistically significant effect on private capital formation in the first two periods for Egypt and Tunisia. In the case of Jordan, the effect is significant only in the second period. Moreover, in the case of Egypt, the growth rate of output increases significantly in the first 3 periods, which seems to occur without any significant pressure on domestic prices (and thus no tendency for the real exchange rate to appreciate); thus, the rise in the investment ratio may also reflect an indirect accelerator effect.

Overall, therefore, our results indicate that there are significant, albeit relatively small in absolute terms and short-lived, "flow" and "stock" effects of public infrastructure on private investment in Egypt, and a significant "stock" effect in Jordan and Tunisia, with no evidence of a "flow" effect. To assess whether the increase in the quality-adjusted infrastructure public capital stock reflects an increase in the stock itself (that is, the "raw" quantity of capital) or a change in quality, we reestimated the VAR model for each country with the unadjusted capital stock. The results showed no significant effects associated with an innovation in the capital stock in Egypt and Tunisia. Moreover, in the case of Jordan, the private investment ratio actually fell slightly on impact. Our interpretation of these results is thus that quality matters for all three countries. Increasing the quantity of infrastructure, by itself, does not have a significant effect on the ratio of private investment to output.

\footnotetext{
${ }^{15}$ The impulse responses and their associated confidence intervals are computed using Monte Carlo simulations employing 1,000 draws. A complete set of results for all the variables in the VAR
} 


\section{POLICY IMPLICATIONS}

Our empirical results have useful policy implications not only for the three countries in our sample but for the MENA region in general. As concluded in a recent report by the World Bank (2004), stimulating growth and job creation in MENA will require comprehensive policy reforms. A key issue in this context, as noted earlier, is the role of the public sector, including in investment provision and institution building. We view our study as bringing to the fore two main policy messages: the first is that the quality of public investment, and specifically infrastructure, matters. The second is that the weak effect of public capital on private investment may reflect the fact that the complementarity effect, while potentially important, may not "kick in" because of an unfavorable environment for private sector activity.

Regarding the first message, an implication of our results is indeed that it may be more important, in some countries, to improve the quality of the existing infrastructure than to engage in further investment. Reducing unproductive public capital expenditure and improving quality must be accompanied by policy reforms aimed at limiting investment to infrastructure capital that crowds in the private sector and/or corrects for fundamental market failures. ${ }^{16}$ To do so requires redefining the role of the public sector as a catalyst, rather than a provider, of the majority of infrastructure services. This will entail privatization and greater involvement of the private sector in infrastructure investment. Such involvement will allow commercial discipline to be introduced in the delivery of services, thereby improving efficiency and the quality and coverage of services, lowering costs, and reducing the burden on the public budget.

model are available upon request.

${ }^{16}$ The existence of market failures is not, of course, an automatic justification for government involvement; such failures only provide a presumption of the need for government intervention. Moreover, even when it is required or desirable, intervention can take many forms; direct public provision is only one of them, and not necessarily the best one. In practice, one has to take into account possible government failures, and compare the costs and benefits of both options. 
Private sector involvement in the delivery of basic infrastructure has indeed increased in developing countries. According to a comprehensive report by the International Finance Corporation (2003), during the 1990s, more than 130 developing countries pursued (through a variety of schemes) private participation in that sector. During the period 1990-2001, for developing countries in general, private participation accounted for 25 percent of total investment in infrastructure. However, the same report notes that in MENA investment in infrastructure projects with private participation fell (in 2001 US dollars) from 3.6 billion in 1993 to \$2.8 billion in 2001. Cumulative investment in the region for the period 1990-2001 (again, in 2001 US dollars) amounted to $\$ 22.8$ billion, which was less than in Sub-Saharan Africa ( $\$ 23.4$ billion) and South Asia (\$39.6 billion), and even more so compared to East Asia and the Pacific ( $\$ 210.6$ billion), Europe and Central Asia (\$97.1 billion), and Latin America and the Caribbean ( $\$ 360.6$ billion). ${ }^{17}$

The second policy message of our study is that the lack of a strong effect of public infrastructure on private investment may reflect the unfavorable environment in which the private sector has operated in the region. Indeed, a key conclusion of recent research by the World Bank (2003b) is that the unfavorable investment environment in MENA goes a long way toward accounting for the lack of a strong response from the private sector in the last decade. While infrastructure (in the form of the provision of critical telecommunications, transport, and energy services) is important, other improvements in the environment in which domestic investment is conducted are crucial. These include, inter alia, the need to provide financing on adequate terms, and guarantee a secure and efficient judicial system. Without renewed effort to tackle these issues, private investment may not achieve its potential to stimulate growth and job creation in the region.

${ }^{17}$ In MENA as elsewhere, a large share of these investments focused on telecommunications (44 percent for all developing countries) and electricity (28 percent). See International Finance Corporation (2003) Harris (2003), and Kessides (2004), for more details. 


\section{Appendix A \\ Public Investment and Private Capital Formation: Some Recent Evidence}

A number of recent studies have attempted to assess empirically the link between public investment and private capital formation, in addition to those related to MENA countries cited in the introduction. This Appendix provides a brief summary of the main results of these studies.

A first group of studies focused on the link between total public investment and private investment, using both individual-country based regressions (in some cases based on cointegration techniques) and dynamic panel regressions. ${ }^{18}$ Examples of regression models include Akkina and Celebi (2002), Apergis (2000), Erenburg and Wohar (1995), Ibrahim (2001), Laopodis (2001), Dhumale (2000), Ramírez (2000), and Narayan (2004). For instance, Apergis (2000), using cointegration techniques, found that the relationship between public and private investment in Greece was positive during the period 1948-80 but negative during the period 1981-86. The latter sample coincided with a period during which the share of public investment in total investment increased sharply. in a study of 8 Latin American countries during the period 1980-95, Ramírez (2000) found that public investment expenditure had a positive (albeit lagged) effect on private capital formation, suggesting a "crowding in" effect. Narayan (2004), using a bivariate framework, found that public and private investment were cointegrated in Fiji during the period 1950-75; in the long run, a 1 percent increase in government investment led to an increase in private investment of between 1.1 and 1.6 percent.

Panel studies focusing on the link between total public investment and private investment include Easterly and Rebelo (1993), Ghura and Goodwin (2000), Miller and Tsoukis (2001), and Everhart and Sumlinski (2001). For instance, Ghura and Goodwin (2000), using panel regression techniques, studied the determinants of private investment in a group of 31 countries in Asia, Latin America, and subSaharan Africa. They found that while total public investment had a positive and significant impact on private capital formation in sub-Saharan Africa, it had the opposite effect in Asia and Latin America. Similar results were obtained by Everhart and Sumlinski (2001), using a broader sample.

Another group of studies have attempted to quantify the effects of various components of public investment on private capital formation. A first set of contributions in that literature has focused on the effects of changes in public capital in infrastructure on factor demand and output (and thus indirectly on private investment, assuming that the accelerator effect is sufficiently strong). For instance, Demetriades and Mamuneas (2000) found that public infrastructure capital has a significant and positive effect on the demand for private inputs and the supply of output in a sample of 12 industrialized countries. The elasticity of output with respect to public capital ranges from 0.4 for the United Kingdom to about 2 for Norway, with

\footnotetext{
${ }^{18} \mathrm{~A}$ third technique is vector autoregression models, which is discussed in the text.
} 
estimates of about 1 for the United States and 0.5 for Japan. Similar elasticities for other countries are scarce, and usually focus on total public capital. Ligthart (2000), for instance, found an elasticity of output with respect to public capital of about 0.4 for Portugal, whereas Naqvi (2003) found that public capital has large positive externalities in Pakistan and is significantly more productive than private capital, with an output elasticity close to 0.5 (as opposed to 0.3 for private capital).

A second set of contributions has focused more directly on the effects of components of public investment on private capital formation. Ahmed and Miller (2000), using a sample of 39 industrial and developing countries for the period 197584 , found that expenditure on social security and welfare reduces private investment (through crowding out effects) in both groups of countries, whereas expenditure on transport and communication raises aggregate investment in developing countries. In a contribution focusing on Latin America, Calderón and Servén (2002) argued that the lack of investment in infrastructure (most notably in roads, telecommunications, and power generation capacity) relative to other developing regions during the past two decades had an adverse effect on productivity, production costs, and investment by the private sector, and dampened output growth in the region. Pereira (2000), using a breakdown of public investment in "core" infrastructure into a) transportation (highways and streets), b) electric and gas facilities, transit systems, and airfields; and $c$ ) sewage and water supply systems, found that in the United States all types of public investment have a positive effect on private investment.

Most of these results, based on either individual-country or dynamic panel regressions, suffer from two fundamental limitations. First, they do not account explicitly for simultaneous interactions between public investment, private investment, and other variables such as the real exchange rate. Second, and related to the first point, they do not account for the government budget constraint, and therefore provide unreliable estimates of the impact of public investment on private capital formation. As noted in the first part of the paper, this impact depends very much on how the increase in public spending is financed. 


\section{Appendix B Data Sources and Definitions}

This Appendix provides a brief description of the data used in this study. The actual dataset is available upon request.

Gross fixed capital formation by the private sector in percent of GDP: For Egypt, the data source is International Finance Corporation (IFC) for 1982-99, and World Development Indicators (WDI) for 2000-02. For 1965-81, the shares of total public and private investment are applied to total fixed capital formation to construct the private fixed capital formation investment series. Series on total public and private investment for 1965-81 were provided by the Bank's desk economist. Jordan: The data source is WDI. Tunisia: The data source is WDI.

Claims on private sector in percent of GDP: The data source is IFS.

Growth rate of the real effective exchange rate: defined as the log difference of the real effective exchange rate. Between 1980-2002, the data source is IFS (1 over the IMF definition). Before 1980, the real effective exchange rate is calculated as the ratio of the nominal exchange rate times the unit value of imports, to the consumer price index. The data source of these variables is IFS and the base year of each variable is 1990. The growth rate of this series is used to construct the real effective exchange rate series before 1980 .

Growth rate of real GDP: defined as the log difference of real GDP, in constant 1990 local currency units (LCU). The data source is WDI.

Gross fixed capital formation by the public sector in percent of GDP: For Egypt, the data source is IFC for 1982-99, and WDI for 2000-02. For 1965-81, the shares of total public and private investment are applied to total fixed capital formation to construct the public fixed capital formation investment series. Series on total public and private investment for $1965-81$ were provided by the Bank's desk economist. Jordan: The data source is WDI. Tunisia: The data source is WDI.

Public capital expenditure infrastructure: The data source is the IMF's Government Finance Statistics (GFS). It is obtained by adding the following series: mining and mineral resources, manufacturing and construction; fuel and energy; railway, air, pipeline, and other transportation; water transport; transportation and communication; other transportation and communication; Housing and community amenities. This series is deflated by the GDP deflator to calculate a series in constant LCU. 
Public infrastructure capital stock in constant LCU: calculated as INF_K(t) = Real public infrastructure expenditure(t-1) + (1-depreciation rate) times INF_K(t-1). The depreciation rate is $2.5 \%$. The initial stock is not available and is set to zero. ${ }^{19}$

Adjusted public infrastructure capital stock in constant LCU: INF_K series is adjusted by multiplying it by the quality index for public infrastructure capital investment, normalized at unity in the first period of estimation.

Composite quality index: is the weighted average of the two principal components, using as weights the proportion of total variance explained by each component. The principal components are calculated over two separate indicators: an ICOR-based measure (defined as the average of 1 over ICOR for public infrastructure capital investment at period $\mathrm{t}, \mathrm{t}-1, \mathrm{t}-2$, and $\mathrm{t}-3$, with ICOR itself defined as nominal public infrastructure investment divided by the change in nominal GDP) and an "excess demand" measure, defined as the average over periods $t, t-1, t-2$, and $t-3$, of the three individual indicators for the quality of public infrastructure capital defined in the text.

${ }^{19}$ Nehru and Dhareshwar (1993) use three-year averages of investment to estimate the initial stock of capital. Larson et al. (2000) estimate the initial level of investment by using a regression of the log of investment on time. Both methods, however, are somewhat arbitrary. 


\section{References}

Agénor, Pierre-Richard, The Economics of Adjustment and Growth, second edition, Harvard University Press (Boston, Mass.: 2004).

Agénor, Pierre-Richard, Mustapha K. Nabli, Tarik Yousef, and Henning T. Jensen, "Labor Market Reforms, Growth, and Unemployment in Labor-Exporting Countries in the Middle East and North Africa," Policy Research Working Paper No. 3328, World Bank (June 2004).

Ahmed, Habib, and Stephen M. Miller, "Crowding-Out and Crowding-In Effects of the Components of Government Expenditure," Contemporary Economic Policy, 18 (January 2000), 124-33.

Akkina, Krishna R., and Mehmet A. Celebi, "The Determinants of Private Fixed Investment and the Relationship between Public and Private Capital Accumulation in Turkey," Pakistan Development Review, 41 (Autumn 2002), 243-54.

Apergis, Nicholas, "Public and Private Investments in Greece: Complementary or 'Substitute' Goods?," Bulletin of Economic Research, 52 (July 2000), 225-34.

Belloc, Marianna, and Pietro Vertova, "How Does Public Investment affect Economic Growth in HIPC? An Empirical Assessment," Working Paper No. 416, University of Siena (January 2004).

Calderón, César, and Luis Servén, "The Output Cost of Latin America's Infrastructure Gap," Working Paper No. 186, Central Bank of Chile (October 2002).

------, "Trends in Infrastructure in Latin America, 1980-2001," Policy Research Working Paper No. 3401, World Bank (September 2004a).

-----, "The Effects of Infrastructure Development on Growth and Income Distribution," Policy Research Working Paper No. 3400, World Bank (September 2004b).

Canning, David, "A Database of World Infrastructure Stocks, 1950-95," World Bank Economic Review, 12 (September 1998), 529-47.

Chirinko, Robert S., "Business Fixed Investment Spending: A Critical Survey of Modelling Strategies, Empirical Results, and Policy Implications," Journal of Economic Literature, 31 (December 1993), 1875-911.

Cohen, Jeffrey P., Catherine J. M. Paul, "Public Infrastructure Investment, Interstate Spatial Spillovers, and Manufacturing Costs," Review of Economics and Statistics, 86 (May 2004), 551-60. 
Demetriades, Panicos, and Theofanis P. Mamuneas, "Intertemporal Output and Employment Effects of Public Infrastructure Capital: Evidence from 12 OECD Economies," Economic Journal, 110 (July 2000), 687-712.

Dhumale, Rahul, "Public Investment in the Middle East and North Africa: Towards Fiscal Efficiency," Development Policy Review, 18 (June 2000), 307-24.

Easterly, William, and Sergio Rebelo, "Fiscal Policy and Economic Growth," Journal of Monetary Economics, 32 (December 1993), 417-58.

Erenburg, S. J., and Mark E. Wohar, "Public and Private Investment: Are there Causal Linkages?," Journal of Macroeconomics, 17 (Winter 1995), 1-30.

Esfahani, Hadi, Maria T. Ramírez, "Institutions, Infrastructure, and Economic Growth," Journal of Development Economics, 70 (April 2003), 443-77.

Estache, Antonio, "Emerging Infrastructure Policy Issues in Developing Countries: A Survey of the Recent Economic Literature," Policy Research Working Paper No. 3442, World Bank (November 2004).

Everhart, Stephen S., and Mariusz A. Sumlinski, "The Impact on Private Investment of Corruption and the Quality of Public Investment," Discussion Paper No. 44, International Finance Corporation (October 2001).

Fay, Marianne, and Tito Yepes, "Investing in Infrastructure: What is Needed from 2000 to 2010?," Policy Research Working Paper No. 3102, World Bank (July 2003).

Ghura, Dhaneshwar, and Barry Goodwin, "Determinants of Private Investment: A Cross-Regional Empirical Investigation," Applied Economics, 32 (November 2000), 1819-29.

Ghali, Khalifa A., "Public Investment and Private Capital Formation in a Vector Error-Correction Model of Growth," Applied Economics, 30 (June 1998), 837-44.

Hakura, Dalia S., "Growth in the Middle East and North Africa," Working Paper No. 04/56, International Monetary Fund (April 2004).

Harris, Clive, "Private Participation in Infrastructure in Developing Countries: Trends, Impacts, and Policy Lessons," World Bank (June 2003).

Hulten, Charles R., "The Measurement of Capital," in Fifty Years of Economic Measurement, ed. by Ernst R. Berndt and Jack E. Tripplett, University of Chicago Press (Chicago, III.: 1990).

------, "Infrastructure Capital and Economic Growth: How Well you Use it may be more Important than how much you Have," Working Paper No. 5847, National Bureau of Economic Research (December 1996). 
Ibrahim, Mansor H., "The Effects of Government Spending on Private Capital Formation: The Case of Malaysia," Economia Internazionale, 54 (May 2001), 187201.

International Finance Corporation, Private Participation in Infrastructure: Trends in Developing Countries in 1990-2001, International Finance Corporation (Washington DC: 2003).

Jackson, J. Edward, A User's Guide to Principal Components, John Wiley and Sons (New York: 1991).

Kessides, loannis N., Reforming Infrastructure: Privatization, Regulation, and Competition, World Bank (Washington DC: 2004).

Laopodis, Nikiforos., "Effects of Government Spending on Private Investment," Applied Economics, 33 (October 2001), 1563-77.

Larson, Donald F., Rita Butzer, Yair Mindlak, and Al Crego, "A Cross-Country Database for Sector Investment and Capital," World Bank Economic Review, 14 (May 2000), 371-91.

Ligthart, Jenny E., "Public Capital and Output Growth in Portugal: An Empirical Analysis," Working Paper No. 00/11, International Monetary Fund (January 2000).

Mamatzakis, E. C., "Public Infrastructure and Private Output: An Application to Greece," Journal of Economic Development, 27 (December 2002), 143-60.

Mansouri, Brahim, "Déséquilibres financiers publics, investissement privé et croissance au Maroc," unpublished, Cadi Ayyad University, Marrakesh (March 2004).

Miller, James, and Christopher Tsoukis, "On the Optimality of Public Capital for Long-run Economic Growth," Applied Economics, 33 (July 2001), 1117-29.

Mittnik, Stefan, and Thorsten Neumann, "Dynamic Effects of Public Investment: Vector Autoregressive Evidence for Six Industrialized Countries," Empirical Economics, 26 (June 2001), 429-36.

Nabli, Mustapha K., and Jennifer Keller, "The Macroeconomics of Labor Market Outcomes in MENA over the 1990s: How Growth has Failed to Keep Pace with a Burgeoning Labor Market," unpublished, World Bank (April 2002).

Naqvi, Naveed H., "Is Public Capital more Productive than Private Capital? Macroeconomic Evidence from Pakistan, 1965-2000," unpublished, University of Durham (September 2003).

Narayan, Paresh K., "Do Public Investments Crowd Out Private Investments? Fresh Evidence from Fiji," Journal of Policy Modeling, 26 (September 2004), 747-53. 
Nehru, Vikram, and Ashok Dhareshwar, "A New Database on Physical Capital Stock: Sources, Methodology, and Results," Revista de Analisis Economico, 8 (June 1993), 37-59.

Page, John, "From Boom to Bust-And Back? The Crisis of Economic Growth in the Middle East and North Africa," in Prospects for Middle Eastern and North African Economies: From Boom to Bust and Back?, ed. by Nemat Shafik, St. Martin's Press (New York: 1998).

Pereira, Alfredo M., "Is all Public Capital Created Equal?," Review of Economics and Statistics, 82 (September 2000), 513-18.

Pritchett, Lant, "Has Education had a Growth Payoff in the MENA Region?," Discussion Paper No. 18, MENA Region, the World Bank (June 1999).

Ramírez, Miguel D. "The Impact of Public Investment on Private Investment Spending in Latin America: 1980-95," Atlantic Economic Journal, 28 (June 2000), 210-25.

Richards, A., and J. Waterbury, A Political Economy of the Middle East, 2nd ed. Westview Press (Boulder, Co : 1996).

Shafik, Nemat, "Modeling Private Investment in Egypt," Journal of Development Economics, 39 (June 1992), 263-77.

Turnovsky, Stephen J., "Fiscal Policy, Adjustment Costs, and Endogenous Growth," Oxford Economic Papers, 48 (July 1996), 361-81.

Voss, Graham M., "Public and Private Investment in the United States and Canada," Economic Modeling, 19 (August 2002), 641-64.

World Bank, Investing in Infrastructure, World Development Report 1994, Oxford University Press (New York: 1994).

-----, Claiming the Future: Choosing Prosperity in the Middle East and North Africa (Washington DC: 1995).

-----, Jobs, Growth and Governance in the Middle East and North AfricaUnlocking the Potential for Prosperity (Washington DC: 2003a).

-----, Trade, Investment and Development in the Middle East and North Africa, World Bank (Washington DC: 2003b).

-----, Unlocking the Employment Potential in the Middle East and North Africa: Towards a New Social Contract, World Bank (Washington DC: 2004). 
Figure 1

MENA Countries: Public and Private Investment

(in percent of GDP)
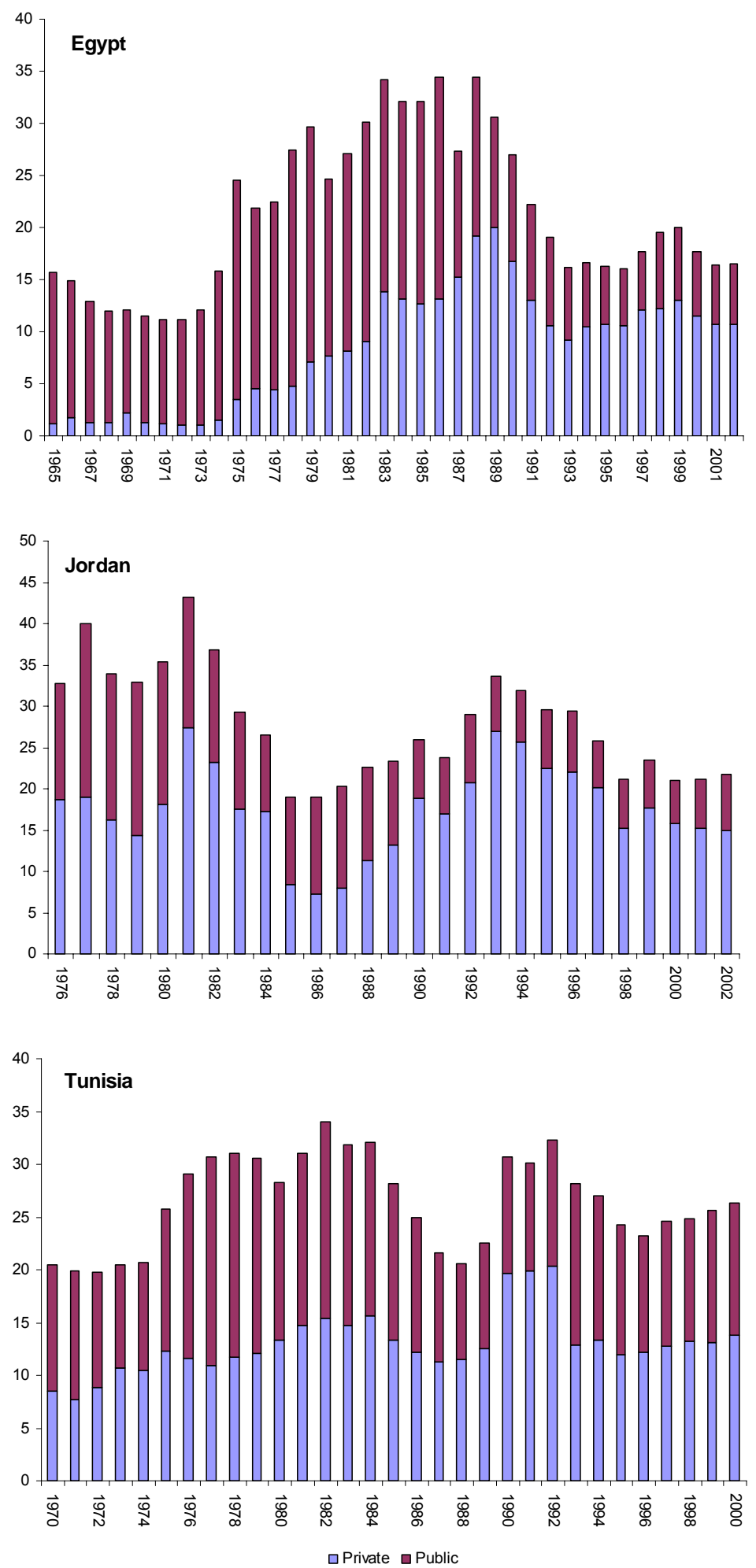
Figure 2

MENA Countries: Capital Expenditure Data

(in percent)
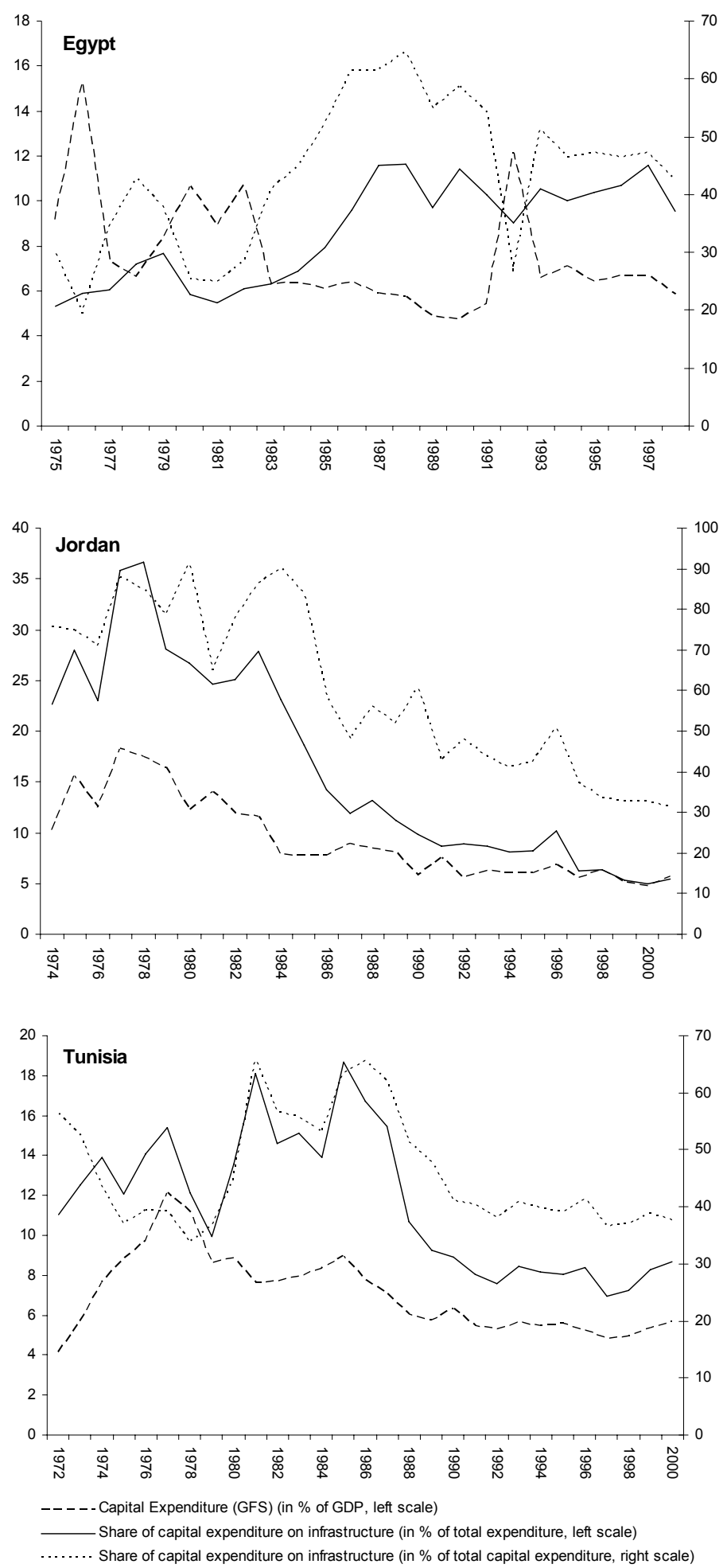

Source: IMF Government Finance Statistics. 
Figure 3

MENA Countries: ICOR-Based Quality Indicator

(Moving Average)

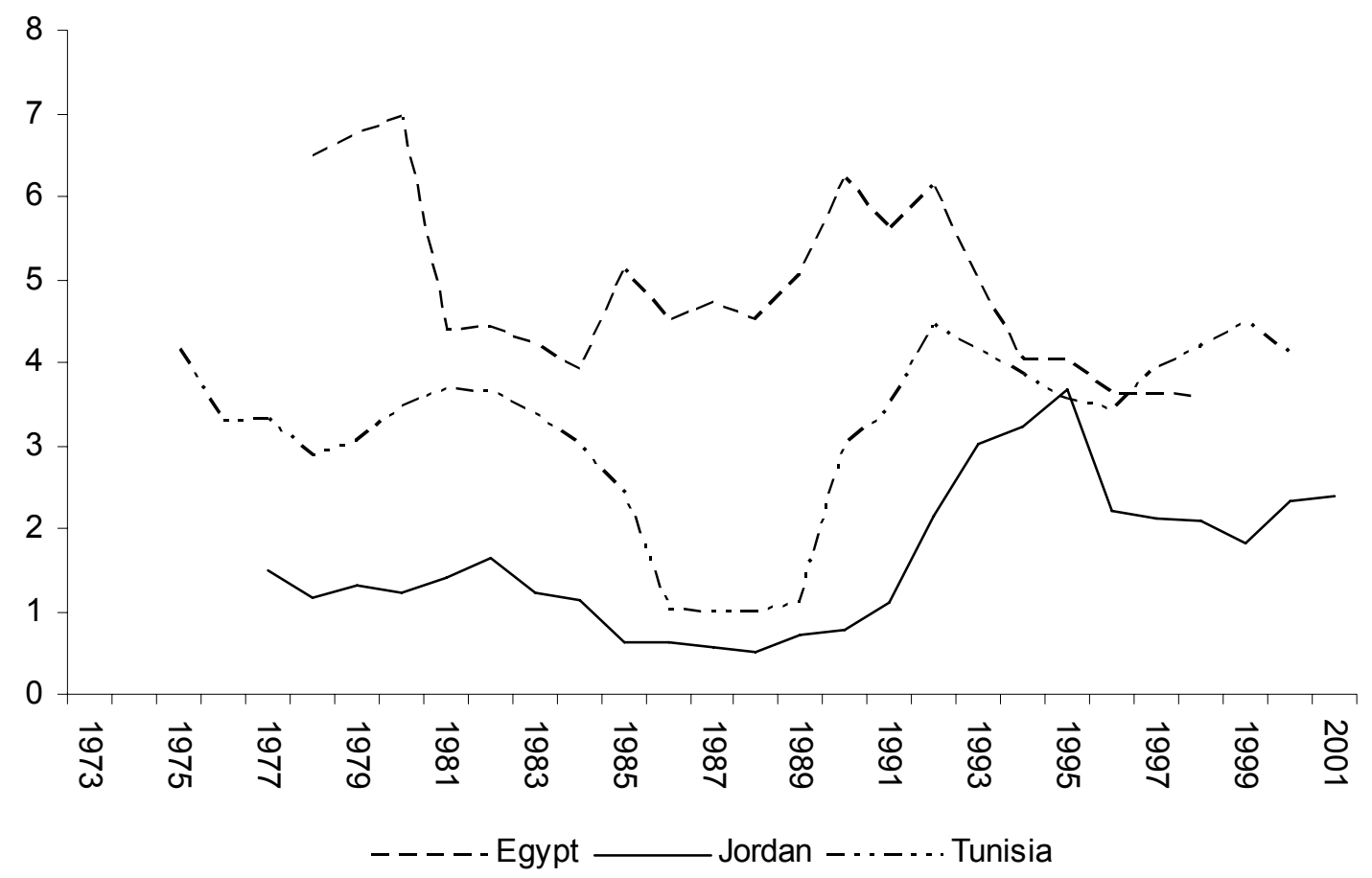

Note: DEFINITION. 
Figure 4

MENA Countries: Excess Demand Quality Indicator

(Moving Average, $1977=1$ )

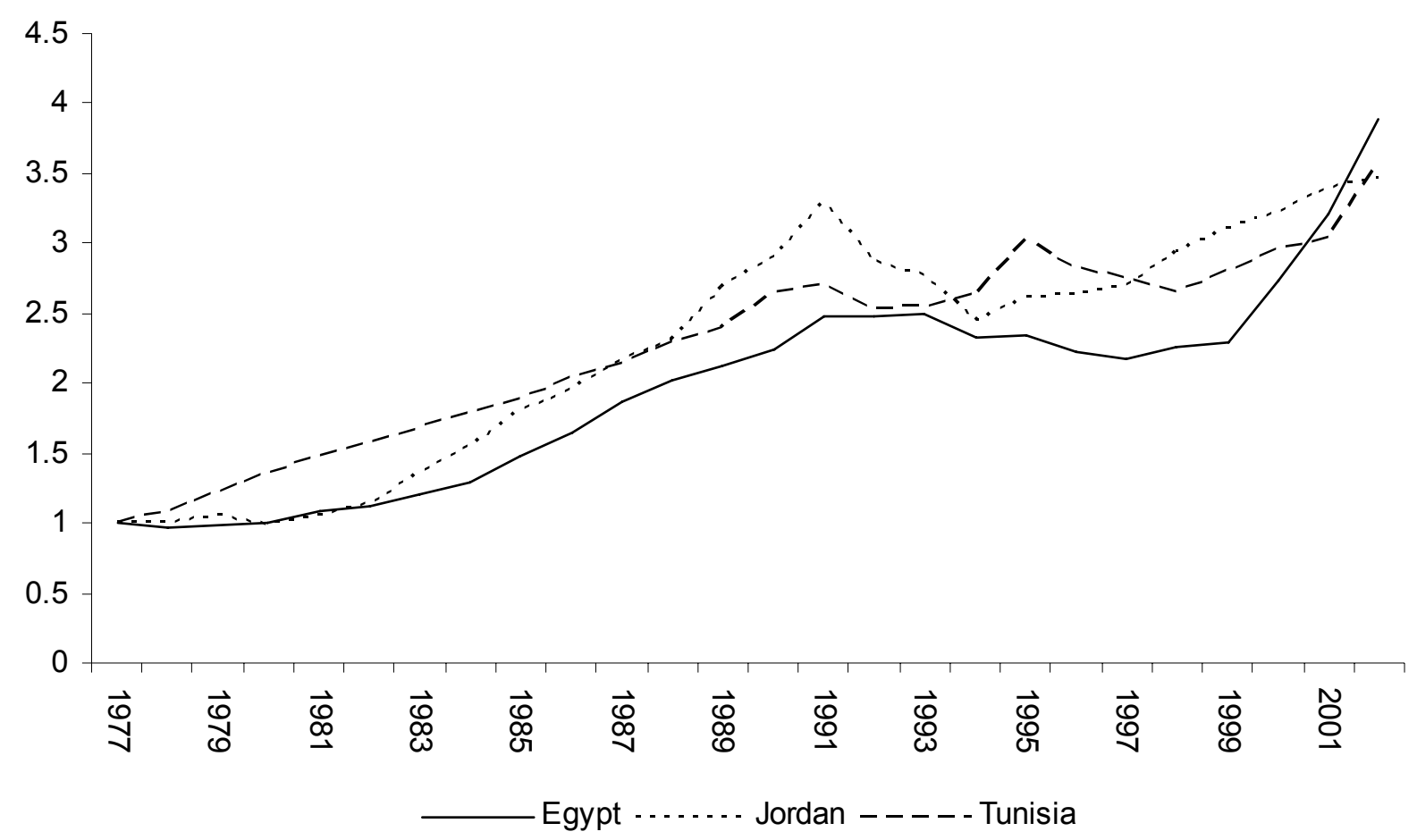


Figure 5

Egypt: Variance Decomposition of Private Investment in percent of GDP

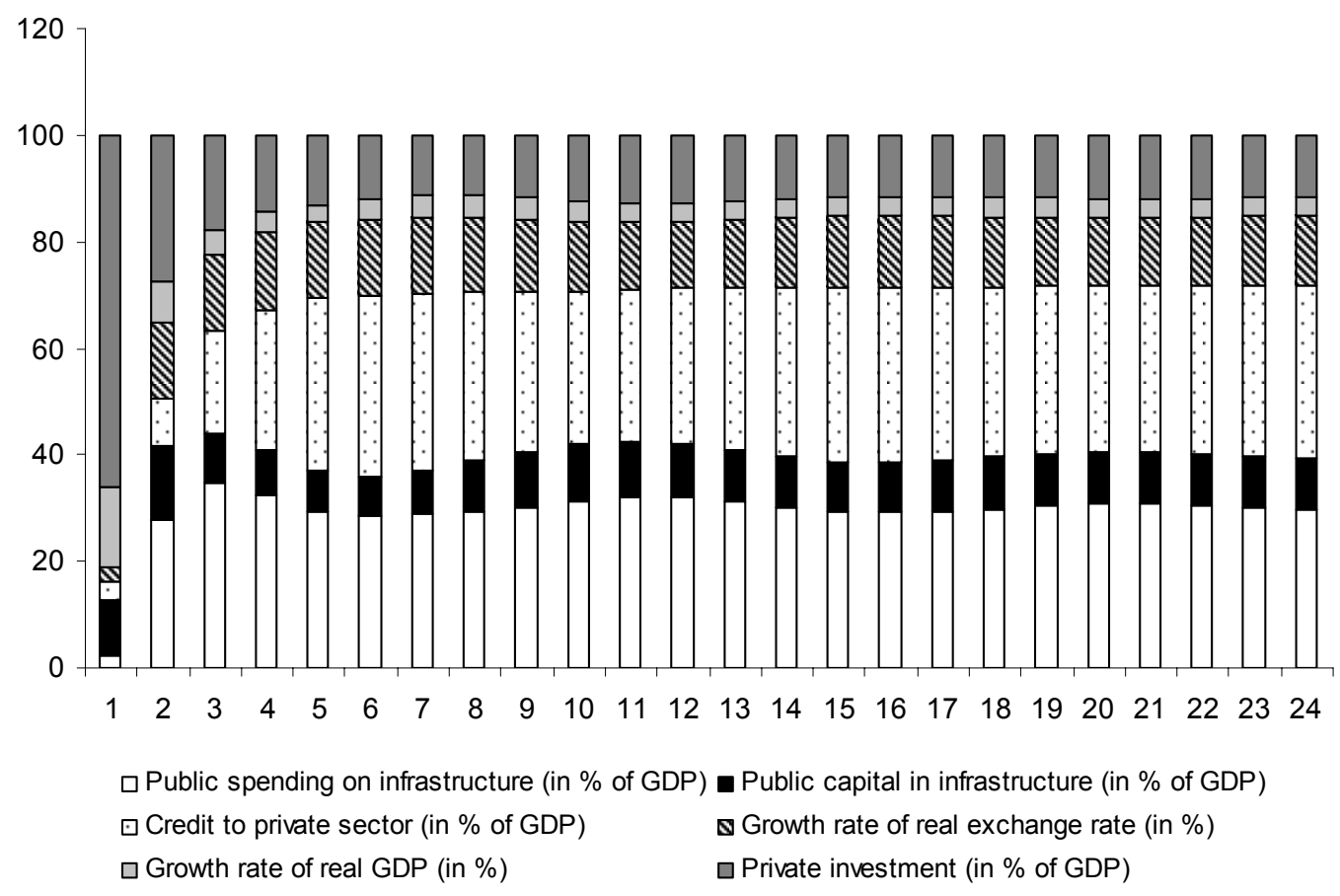


Figure 6

Jordan: Variance Decomposition of Private Investment in percent of GDP

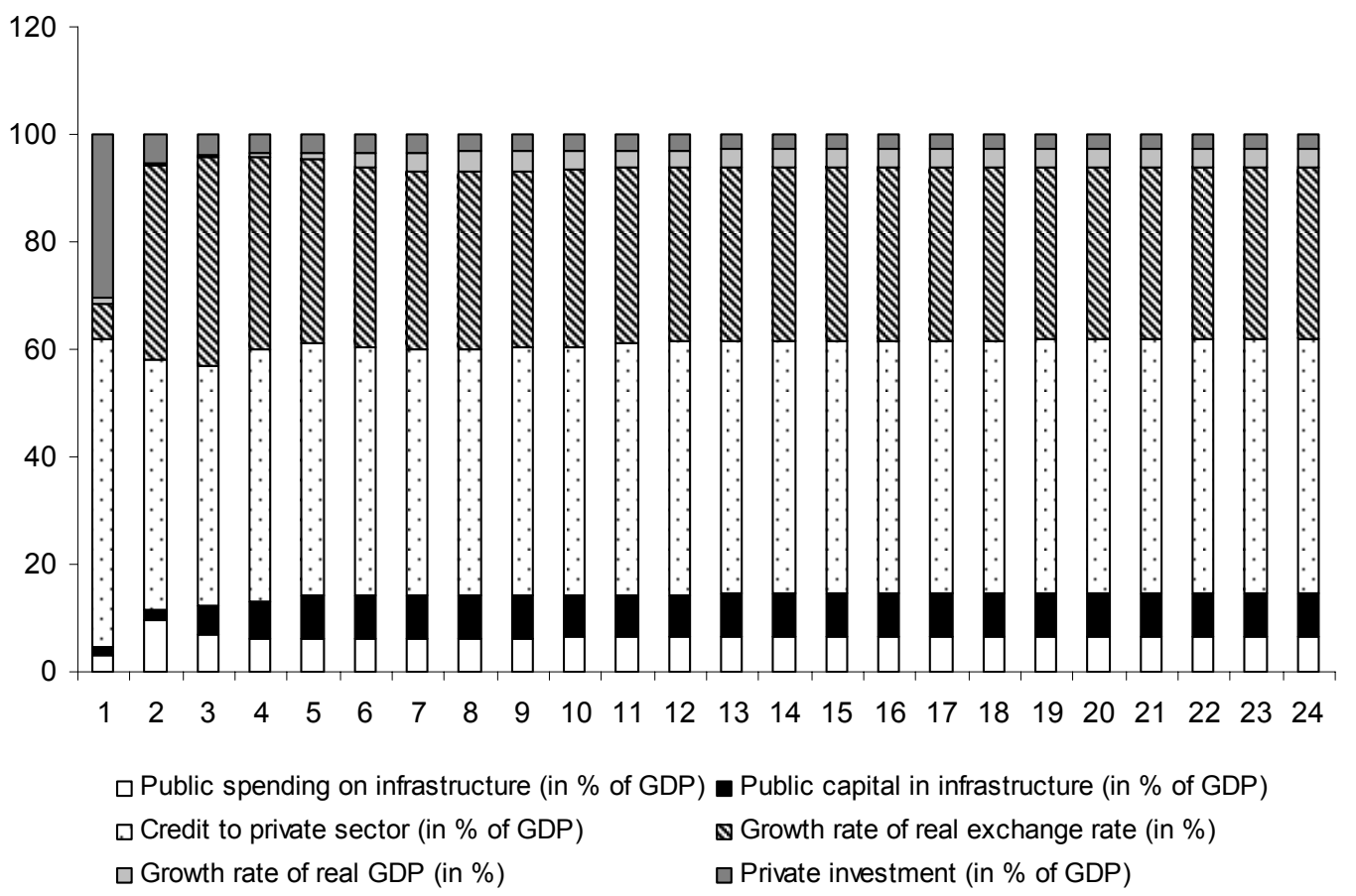


Figure 7

Tunisia: Variance Decomposition of Private Investment in percent of GDP

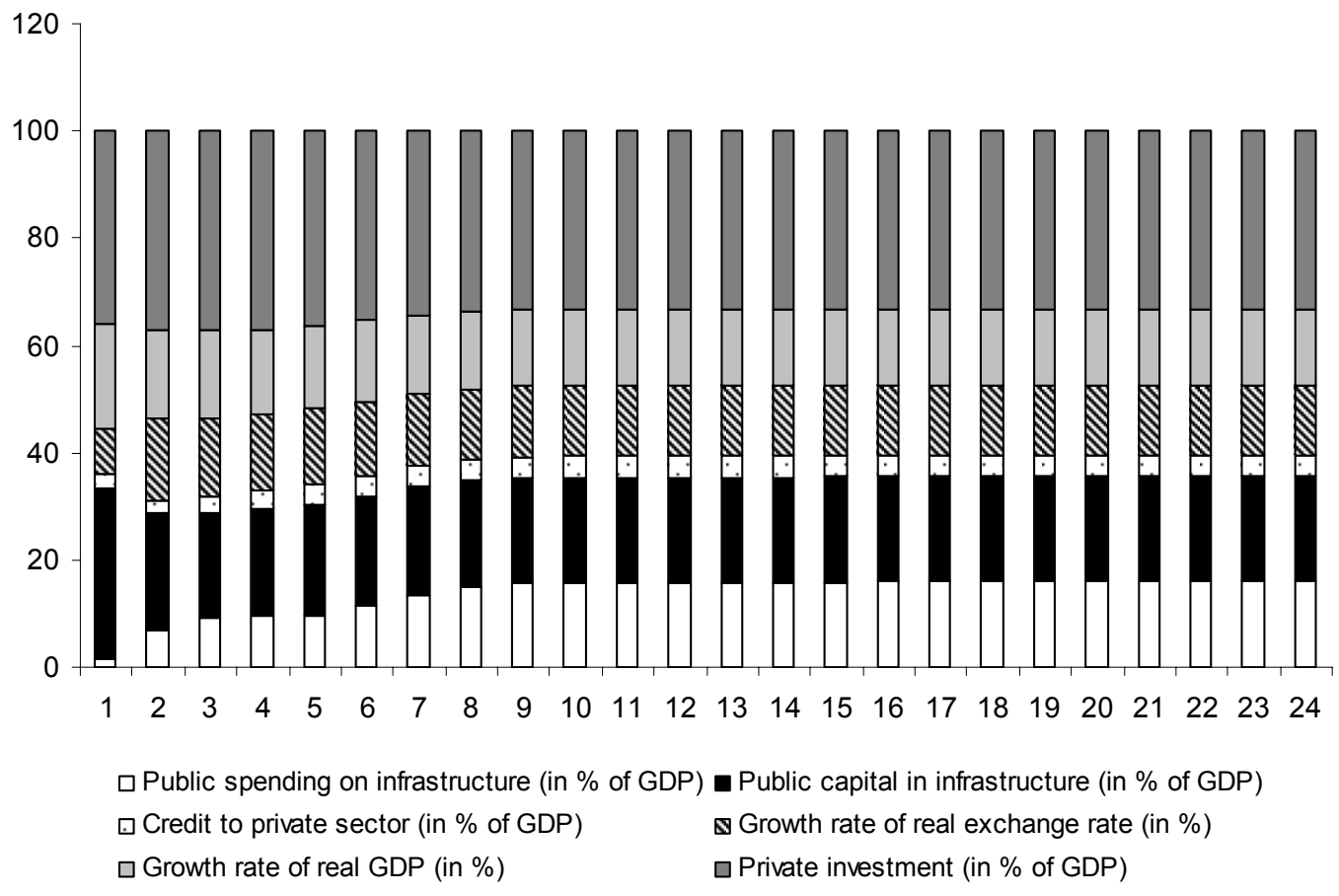


Figure 8

MENA Countries: Response of Private Investment in percent of GDP to One Standard Deviation Innovation in Public Spending on Infrastructure or in Public Capital Stock in Infrastructure, both in percent of GDP

(+l- 2 standard errors)

Innovation in Public Spending on Infrastructure

(in \% of GDP)

Egypt

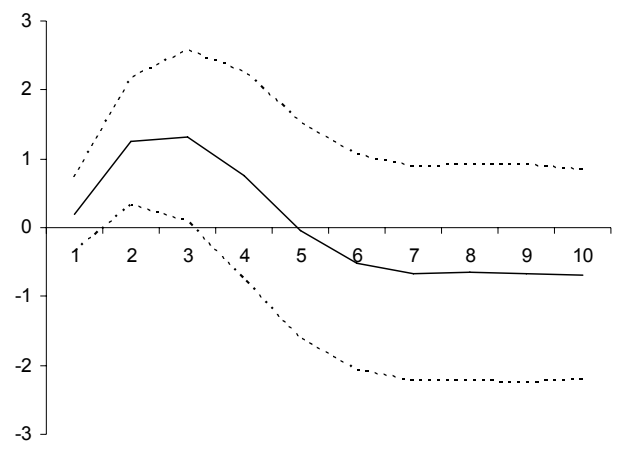

Jordan

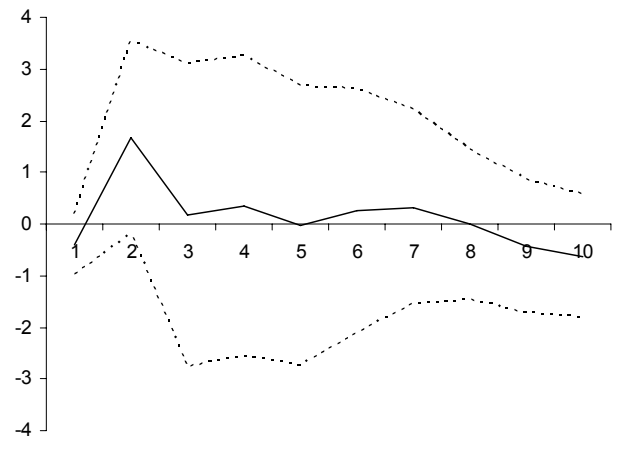

Tunisia

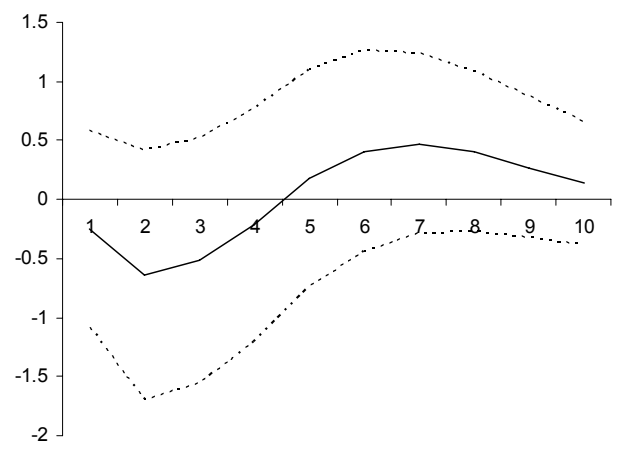

Innovation in Public Capital Stock in Infrastructure (in \% of GDP)
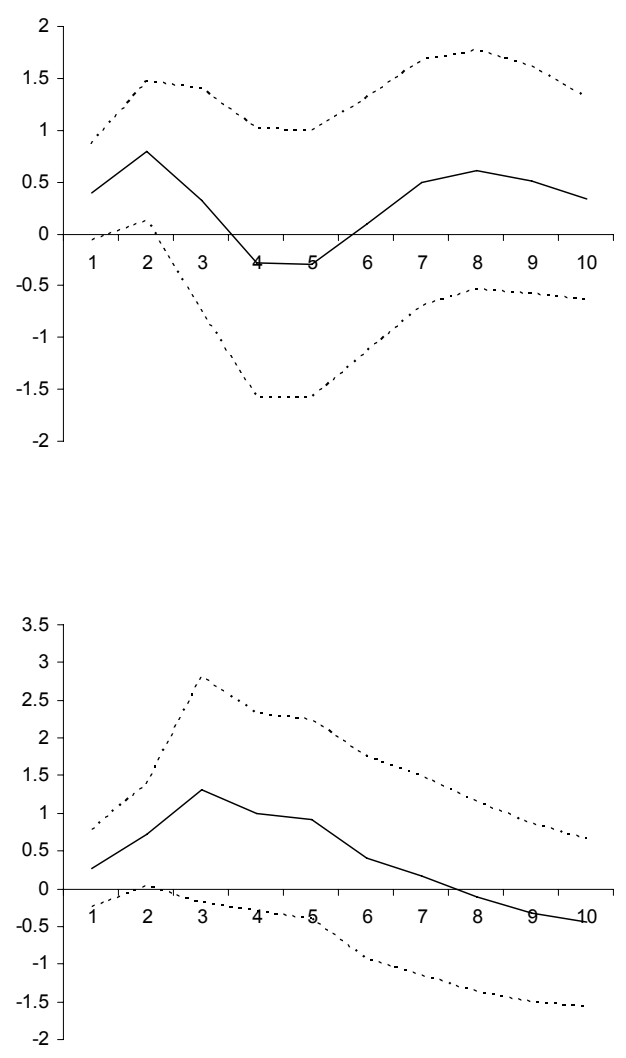